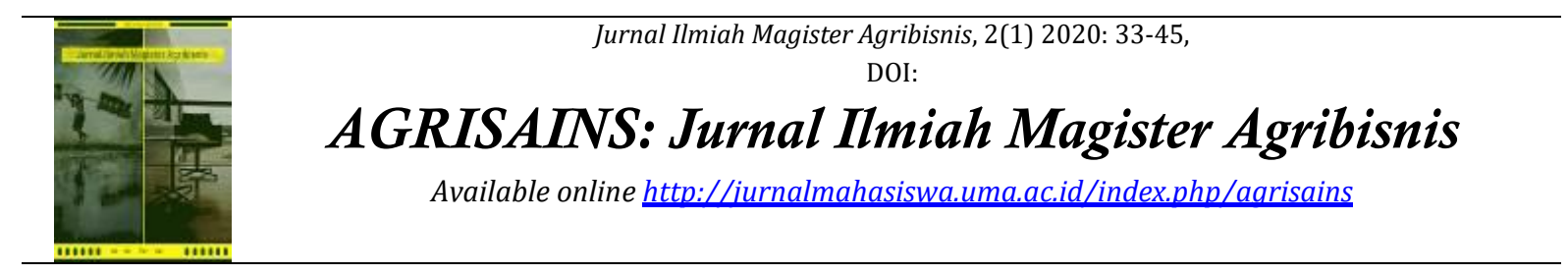

\title{
Analisis Perbedaan Pendapatan Usahatani Padi Sawah Sistem Tanam Jajar Legowo 2 : 1 Dengan 4 : 1 di Kecamatan Kualuh Selatan Kabupaten Labuhanbatu Utara
}

\section{The Analysis of Difference in Income of Rice Field Cultivation System for Jajar Legowo 2: 1 with 4 : 1 in South Kualuh Subdistrict, North Labuhanbatu Regency}

\author{
Safriadi1), Tumpal H.S. Siregar-2), E. Harso Khardinata $^{3 \text { ) }}$
}

1) Program Studi Magister Agribisnis, Pascasarjana, Universitas Medan Area, Indonesia 2) Magister Agribisnis, Pascasarjana, Universitas Medan Area, Indonesia

3) Fakultas Pertanian, Universitas Sumatera Utara, Indonesia

\begin{abstract}
Abstrak
Penelitian ini bertujuan untuk mengetahui perbedaan pendapatan dan mengetahui kelayakan usahatani padi sawah system tanam jajar legowo $2: 1$ dengan $4: 1$. Bentuk penelitian ini adalah penelitian kuantitatif dengan metode survey dan pengamatan di lapangan. Populasi dalam Penelitian ini adalah masyarakat petani padi sawah di 3 desa yaitu desa Siamporik, desa Gunung Melayu dan Desa Siduadua di Kecamatan Kualuh Selatan Kabupaten Labuhanbatu Utara dan teknik pengambilan sampel secara purposive. Dari hasil penelitian menunjukkan bahwa sistem tanam jajar legowo $2: 1$ dengan $4: 1$ berbeda nyata dalam hal pendapatan secara statisitik, rata-rata pendapatan petani Jarwo $2: 1$ sebesar 14.315.331 dan Jarwo $4: 1$ sebesar 13.863.238 dengan R/C Ratio Jarwo 2 : 1 sebesar 1,247 dan Jarwo $4: 1$ sebesar 1,204, untuk analisis BEP Jarwo $2: 1$ sebesar 4.970 dan analisis BEP Jarwo $4: 1$ sebesar 5.065 .

Kata kunci : Pendapatan, Padi Sawah, Sistem Tanam jajar Legowo
\end{abstract}

\begin{abstract}
This study aims to determine the differences in income and determine the feasibility of a 2: 1 to 4: 1 jowo legowo planting system in rice farming. The form of this research is a quantitative study with survey and observation methods in the field. The population in this study was the community of paddy rice farmers in 3 villages namely Siamporik village, Gunung Melayu village and Siduadua village in Kualuh Selatan District of North Labuhanbatu Regency and purposive sampling technique. The results showed that the legowo row 2: 1 with 4: 1 planting systems were significantly different in terms of static income, the average income of Jarwo 2: 1 farmers was 14,315,331 and Jarwo 4: 1 was 13,863,238 with R / C Jarwo 2: 1 ratio of 1,247 and Jarwo 4: 1 of 1,204, for Jarwo 2: 1 BEP analysis 4,970 and Jarwo 4: 1 BEP analysis of 5,065.
\end{abstract}

Keywords: Income, Paddy Rice, Legowo jajar Planting System

How to Cite: Safriadi, T.H. Siregar, \& E. H. Khardinata. (2020). Analisis Perbedaan Pendapatan Usahatani Padi Sawah Sistem Tanam Jajar Legowo 2:1 Dengan 4:1 di Kecamatan Kualuh Selatan Kabupaten Labuhanbatu Utara. Jurnal Ilmiah Magister Agribisnis, 2(1) 2020: 33-45,

*E-mail: harsokhrdhinata@uma.ac.id ISSN 2550-1305 (Online)

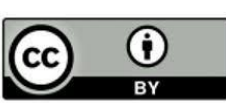


Safriadi, T.H. Siregar, \& E. H. Khardinata. Analisis Perbedaan Pendapatan Usahatani Padi Sawah Sistem Tanam Jajar Legowo 2:1 Dengan 4:1 di Kecamatan Kualuh Selatan Kabupaten Labuhanbatu Utara.

\section{PENDAHULUAN}

Padi (Oryza sativa L.) merupakan tanaman penting dan merupakan komoditi strategis. Padi yang menghasilkan beras merupakan makanan pokok terpenting bagi sebagian besar penduduk Indonesia. Tanaman pangan masih perlu menjadi prioritas utama dalam pengembangan pertanian, karena kebutuhan pangan nasional belum terpenuhi. Oleh karena itu, tidaklah mengherankan kalau ada kenaikan harga beras atau kurangnya stok beras nasional akan berdampak negatif bagi kondisi sosial dan ekonomi masyarakat di negara ini. (Mamarimbing, 2003).

Produksi beras akhir-akhir ini menghadapi berbagai kendala khususnya di Kabupaten Labuhanbatu Utara, diantaranya penerapan teknik budidaya dan penggunaan varietas padi yang kurang tepat. Pengelolaan suatu tanaman akan berhasil karena adanya ketersediaan dan kemampuan tanaman dalam memanfaatkan sumber daya lingkungan. Usaha yang dapat dilakukan untuk mengatasi kendala tersebut misalnya dengan penerapan sistem tanam yang benar dan baik melalui pengaturan jarak tanam, pemupukkan seimbang, pemilihan varietas yang tepat dan pengendalian hama penyakit. Penggunaan varietas tanaman dan pengaturan jarak tanam yang tepat mempunyai pengaruh besar terhadap tingkat produktivitas ( Dinas Pertanian, 2015).

Ada 4 masalah yang berkaitan dengan kondisi perberasan di Indonesia, 1) rata-rata luas garapan petani hanya 0,3 ha, 2) sekitar tujuh $70 \%$ petani padi termasuk golongan masyarakat miskin dan berpendapatan rendah. 3) hampir seluruh petani padi adalah pengkonsumsi beras dan 4) rata-rata pendapatan dari usaha tani padi hanya sebesar 30\% dari total pendapatan keluarga. Dengan kondisi ini pemerintah selalu dihadapkan pada posisi sulit, satu sisi pemerintah harus menyediakan beras dengan harga yang terjangkau oleh masyarakat, dan disisi lain pemerintah harus melindungi petani produsen dan menjaga ketersediaan secara cukup (Achmad, 2006).

Setiap petani dalam pengelolaan usahataninya mempunyai tujuan yang berbeda-beda. Ada tujuannya untuk memenuhi kebutuhan keluarga yang disebut usahatani subsisten, dan ada yang bertujuan mencari keuntungan disebut usahatani komersial. Petani kita umumnya bertujuan untuk mencari keuntungan dalam meningkatkan penghasilan/pendapatannya bukan sematamata untuk memenuhi kebutuhan keluarga (Hermanto, 2001).

Peningkatan produksi padi melalui peningkatkan luas areal produksi menghadapi kendala seiring dengan tingginya tingkat konversi lahan pertanian 
untuk daerah industri dan perumahan, oleh karena itu diperlukan upaya lain dalam rangka meningkatkan produksi padi nasional yaitu dengan peningkatan produktivitas. Dalam melaksanakan usaha tanam padi ada beberapa hal yang menjadi tantangan salah satunya yaitu bagaimana upaya ataupun cara yang harus dilakukan untuk mendapatkan hasil produksi padi yang tinggi. Namun untuk mewujudkan upaya tersebut masih terkendala karena jika diperhatikan masih banyak petani yang belum mau melaksanakan anjuran sepenuhnya. Sebagai contoh dalam hal sistem tanam masih banyak petani yang bertanam tanpa jarak tanam yang beraturan. Padahal dengan pengaturan jarak tanam yang tepat dan teknik yang benar dalam hal ini adalah sistem tanam jajar legowo maka akan diperoleh efisiensi dan efektifitas pertanaman serta memudahkan kelanjutan pengelolaannya (Kementrian Pertanian, 2013).

Kabupaten Labuhanbatu Utara merupakan salah satu kabupaten di Provinsi Sumatera Utara yang memiliki potensi cukup besar dalam bidang pertanian. Tetapi sekarang pertanian tanaman pangan dihadapkan dengan alih fungsi lahan tanaman padi sawah menjadi lahan tanaman perkebunan terutama kelapa sawit dan perumahan penduduk. Hal ini terjadi karena di masa yang lalu petani dihadapkan dengan kenyataan bahwa usahatani padi sawah memberikan pendapatan yang rendah kepada petani sehingga petani lebih memilih usahatani kelapa sawit ataupun usaha lainnya untuk memenuhi kebutuhan keluarga. Tetapi hal itu sudah berubah sekarang karena harga jual gabah padi sudah sangat baik sehingga petani padi sudah memperoleh pendapatan yang layak. Untuk itu penulis memandang penting untuk melakukan penelitian tentang analisis perbedaan pendapatan usahatani padi sawah sistem tanam legowo $2: 1$ dengan $4: 1$ di Kecamatan Kualuh Selatan Kabupaten Labuhanbatu Utara.

\section{METODE PENELITIAN}

Pemilihan lokasi penelitian dilakukan secara sengaja (purposive). Daerah yang dipilih sebagai tempat penelitian yaitu Kecamatan Kualuh Selatan Kabupaten Labuhanbatu Utara. Peneliti menentukan tempat penelitian berdasarkan desa yang memiliki luas sawah terluas, sehingga diambil 3 desa dari 5 (lima) desa yang ada di kecamatan Kualuh Selatan Kabupaten Labuhanbatu Utara yaitu desa Siamporik dengan luas 142 ha, desa Gunung Melayu dengan luas 402 ha, dan desa Sidua-dua dengan luas 232 ha. Waktu penelitian dilaksanakan selama tiga bulan, mulai bulan April sampai dengan bulan Juni tahun 2017. 
Safriadi, T.H. Siregar, \& E. H. Khardinata. Analisis Perbedaan Pendapatan Usahatani Padi Sawah Sistem Tanam Jajar Legowo 2:1 Dengan 4:1 di Kecamatan Kualuh Selatan Kabupaten Labuhanbatu Utara.

Bentuk penelitian ini adalah penelitian kuantitatif dengan metode survey dan pengamatan di lapangan. Populasi dalam penelitian ini adalah masyarakat petani padi sawah di Kecamatan Kualuh Selatan yang terdiri dari 3 (tiga) desa yaitu desa Siamporik, desa Gunung Melayu, dan desa Sidua Dua di Kabupaten Labuhanbatu Utara. Berdasarkan penjelasan tersebut, maka sampel penelitian untuk petani padi sawah yang menggunakan sistem tanam Jajar Legowo 2:1 tercatat berjumlah sebanyak 20 petani dan petani padi sawah yang menggunakan sistem tanam Jajar Legowo 4:1 tercatat berjumlah sebanyak 20 petani sehingga jumlah sampel penelitian berjumlah 40 petani.

Data primer diperoleh melalui wawancara dengan menyediakan kuisioner kepada para responden yaitu petani padi sawah, untuk memperoleh keterangan dan data yang diperlukan dalam penelitian ini. Data sekunder diperoleh dari instansi terkait meliputi BPS Pusat, BPS Labuhanbatu Utara, Dinas Pertanian dan Kantor Kecamatan serta Desa sampel.

\section{Teknik Analisis Data}

Data yang diperoleh dari lapangan baik data primer maupun data sekunder diolah dengan mentabulasikan dan kemudian dipindahkan dalam bentuk tabel sesuai dengan kebutuhan analisis.

\section{Analisis Pendapatan}

\section{Pendapatan Kotor (Penerimaan)}

Pendapatan kotor $=$ Jumlah Produksi $\mathrm{x}$ Harga Per-Satuan

$\mathrm{TR}=(\mathrm{Y}) \times($ Py $) \ldots . . . . .($ Suratiyah, 2009)

Dimana:

TR : Total penerimaan (Total Revenue)

Y : Produk yang diperoleh dalam usahatani (kg)

Py : Harga Y (Price)

\section{Pendapatan Bersih}

Pd = TR - TC ..... ( Soekartawi, 2002)

Dimana :

Pd : Pendapatan usahatani

TR : Penerimaan Total (total revenue)

TC : Biaya total (total cost)

\section{Analisis Finansial}

Selanjutnya untuk analisis kalayakan usahatani padi sawah digunakan analisis financial meliputi: Analisis R/C ratio dan BEP.

\section{R/C Ratio}


Untuk mengetahui kelayakan finansial usahatani padi sawah dari sisi $\mathrm{R} / \mathrm{C}$ rasio menggunakan rumus sebagai berikut:

$\mathrm{R} / \mathrm{C}$ Ratio $=\mathrm{TR} / \mathrm{TC}$

Dimana :

$\mathrm{RCR}=$ Revenue Cost Ratio

$\mathrm{TR}=$ Total Penerimaan

$\mathrm{TC}=$ Total Biaya

Kaidah penerimaan hipotesis:

Jika nilai $\mathrm{R} / \mathrm{C}$ rasio $<1$, maka usahatani padi sawah tidak layak secara finansial

Jika nilai $\mathrm{R} / \mathrm{C}$ rasio $>1$, maka usahatani padi sawah layak secara financial.

Jika nilai $\mathrm{R} / \mathrm{C}$ rasio $=1$, maka usahatani padi sawah dinyatakan impas.

\section{Analisis Break Event Point}

Perhitungan titik impas atau Break Event Point (BEP) berdasarkan dua cara yaitu yang pertama berdasarkan volume produksi/ penjualan dalam unit yaitu pada tingkat produksi berdasarkan jumlah, dan yang kedua berdasarkan harga penjualan.

Rumus 1 atas dasar produksi sebagai berikut:

$\mathrm{BEP}=\frac{F C}{1-\frac{F C}{S}}$

Rumus 2 atas dasar harga jual produksi sebagai berikut:

$\mathrm{BEP}=\frac{F C}{P-V C}$

Dimana:

$\mathrm{BEP}=$ Titik impas

$\mathrm{FC}=$ Biaya tetap

$\mathrm{P}=$ Harga

$\mathrm{AVC}=$ Biaya rata-rata variabel

Analisis Perbedaan Pendapatan Usahatani Padi Sawah sistem tanam jajar legowo 2 : 1 dengan $4: 1$

Untuk menguji perbedaan produksi, penerimaan dan pendapatan usahatani padi sawah dengan sistem tanam jajar legowo $2: 1$ dan $4: 1$ dilakukan dengan uji statistik uji beda rata-rata (Sugiyono, 2010). Formulasinya sebagai berikut: 
Safriadi, T.H. Siregar, \& E. H. Khardinata. Analisis Perbedaan Pendapatan Usahatani Padi Sawah Sistem Tanam Jajar Legowo 2:1 Dengan 4:1 di Kecamatan Kualuh Selatan Kabupaten Labuhanbatu Utara.

$$
\text { thitung }=\frac{\mathrm{d}-\mathrm{do}}{\mathrm{sd} / \sqrt{\mathrm{n}}} ; \mathrm{db}=\mathrm{n}-1^{\mathrm{d}}
$$

Dimana:

$\mathrm{d}-\mathrm{do}=$ Rata-rata produksi/penerimaan/pendapatan usahatani padi sawah sistem tanam jajar legowo $2: 1$ dan $4: 1$

$\mathrm{Sd} \quad=$ Standar deviasi

$\mathrm{n} \quad=$ Jumlah observasi

$\mathrm{db}=$ Derajat Bebas

Uji beda $t$-test digunakan untuk menentukan apakah 2 sampel atau lebih yang tidak berhubungan memiliki nilai rata-rata yang berbeda. Uji beda $t$-test dilakukan dengan cara membandingkan perbedaan antara dua nilai rata-rata dengan standart error dari perbedaan rata-rata dua sampel. Standart error perbedaan dalam nilai rata-rata terdistribusi secara normal. Dapat disimpulkan bahwa uji beda t-test adalah membandingkan rata-rata dua grup yang tidak berhubungan satu dengan yang lainnya.

\section{HASIL DAN PEMBAHASAN}

Pendapatan diperoleh dari hasil penjumlahan antara total penerimaan dikurangi dengan total biaya variabel ditambah biaya tetap dalam usahatani padi sawah jajar legowo 2:1 dan jajar legowo 4:1. Dalam suatu usahatani apabila tingkat penerimaan lebih besar daripada total biaya maka usahatani tersebut akan memperoleh tingkat pendapatan yang maksimal.

Berdasarkan Tabel 1, rata-rata jumlah penerimaan dan produksi padi petani jajar legowo 2:1 lebih besar yaitu Rp 25.792.000, sementara rata-rata jumlah produksi padi sebesar $6.200 \mathrm{~kg}$ dibandingkan rata-rata penerimaan yang diperoleh petani jajar legowo 4:1 yaitu Rp 25.376.000, sementara rata-rata jumlah produksi padi sebesar $6.100 \mathrm{~kg}$. Selisih rata-rata penerimaan keduanya adalah sebesar Rp 416.000 dan selisih produksi padi sebesar $100 \mathrm{~kg}$.

Hal ini disebabkan oleh beberapa faktor diantaranya yaitu sistem tanam padi jajar legowo yang menggunakan benih usia muda saat disemai mampu memproduksi jumlah anakan secara maksimal serta adanya tambahan tanaman sisipan sehingga mempengaruhi jumlah produksi padi. Hasil panen padi baik jajar legowo 2:1 maupun jajar legowo 4:1 dijual langsung di lahan secara tebasan dengan harga yang sama yaitu Rp 4.160/kg. 
Tabel 1. Rata-rata Pendapatan Usahatani Padi Sawah

\begin{tabular}{lll}
\hline Uraian & \multicolumn{2}{c}{ Nilai } \\
\cline { 2 - 3 } & \multicolumn{1}{c}{ Jarwo $2: 1$} & Jarwo \\
\hline Produksi / Ha (kg) & 6.200 & 6.100 \\
Harga (Rp) & 4.160 & 4.160 \\
Rata-rata penerimaan (Rp) & 25.792 .000 & 25.376 .000 \\
Biaya & & \\
Rata-rata biaya tetap (Rp/Ha) & & \\
Pajak Tanah & 82.972 & 82.972 \\
Penyusutan Alat & 108.697 & 119.790 \\
Rata-rata Biaya Variabel (Rp/Ha) & & \\
Benih & 345.000 & 330.000 \\
Pupuk & 1.200 .000 & 1.320 .000 \\
Pestisida & 1.690 .000 & 1.810 .000 \\
Upah & 8.050 .000 & 7.850 .000 \\
Sub. Total (A + B) & 11.476 .669 & 11.512 .762 \\
Rata-rata Pendapatan (3-4) (Rp/Ha) & 14.315 .331 & 13.863 .238 \\
\hline \multicolumn{2}{c}{ Sumber : Data Primer (diolah), } & \\
\hline
\end{tabular}

Sumber : Data Primer (diolah), 2017

Untuk biaya yang dikeluarkan oleh petani jajar legowo 2:1 dan 4:2 untuk benih masing-masing sebesar Rp 345.000 dan Rp 330.000. Perbedaan biaya untuk benih dikarenakan sistem tanam jajar legowo 2:1 lebih banyak menggunakan sisipan dibandingkan dengan sistem tanam jajar legowo 4:1. Biaya yang dikeluarkan untuk pupuk sebesar Rp 1.200 .000 oleh petani jajar legowo 2:1 dan Rp 1.320.000 oleh petani jajar legowo 4:1, perbedaan biaya yang dikeluarkan untuk pupuk ini karena sistem tanam 4:1 memiliki jarak tanam yang banyak.

Berdasarkan Tabel 1 di atas juga terlihat bahwa untuk biaya pestisida oleh petani jajar legowo 2:1 dan 4:1 masing-masing sebesar Rp 1.690.000 dan Rp 1.810.000 sedangkan untuk upah tenaga kerja sistem tanam jajar legowo 2:1 lebih besar dibandingkan sistem tanam jajar legowo 4:1 dengan selisih biaya rata-rata adalah Rp 1.800 .000 dikarenakan jumlah tenaga kerja dan waktu yang dibutuhkan saat penanaman sistem tanam jajar legowo 2:1 lebih banyak.

Kelayakan finansial usahatani padi sawah dari sisi R/C rasio di Kabupaten Labuhanbatu Utara berdasarkan atas analisis yang dilakukan peneliti dapat dilihat dari Tabel 2. Untuk kedua sistem tanam yang dilakukan oleh petani padi sawah diperoleh bahwa kedua sistem tanam tersebut layak diusahakan dengan 
Safriadi, T.H. Siregar, \& E. H. Khardinata. Analisis Perbedaan Pendapatan Usahatani Padi Sawah Sistem Tanam Jajar Legowo 2:1 Dengan 4:1 di Kecamatan Kualuh Selatan Kabupaten Labuhanbatu Utara.

melihat nilai R/C Rasio masing-masing dari kedua sistem tanam tersebut yang bernilai lebih dari 1, dimana $\mathrm{R} / \mathrm{C}$ rasio untuk sistem jajar legowo 2:1 sebesar 1,247 dan untuk sistem jajar legowo 4:1 sebesar 1,204. Jika nilai R/C rasio $>1$, maka usahatani padi sawah layak secara finansial sehingga untuk kaidah penerimaan hipotesis Ha penelitian diterima dan Ho penelitian ditolak.

Tabel 2. R/C Ratio dari Total Penerimaan terhadap Total Biaya

\begin{tabular}{|c|c|c|c|}
\hline Sistem Tanam & $\begin{array}{l}\text { Rata-rata Penerimaan } \\
\text { (TR) }\end{array}$ & $\begin{array}{l}\text { Rata-rata } \\
\text { Biaya (TC) }\end{array}$ & R/C Ratio \\
\hline Jarwo $2: 1$ & Rp 14.315.331 & Rp 11.476.669 & 1,247 \\
\hline Jarwo $4: 1$ & Rp 13.863.238 & Rp 11.512.762 & 1,204 \\
\hline
\end{tabular}

Sumber : Data Primer (diolah), 2017

Tabel 3. Analisa Break Event Point (BEP)

\begin{tabular}{llllll}
\hline $\begin{array}{l}\text { Sistem } \\
\text { Tanam }\end{array}$ & $\begin{array}{l}\text { Total Biaya } \\
\text { (TC) }\end{array}$ & $\begin{array}{l}\text { Produksi } \\
(\text { Kg) }\end{array}$ & $\begin{array}{l}\text { Harga } \\
\text { Jual }\end{array}$ & $\begin{array}{l}\text { Biaya rata- } \\
\text { rata Per kg }\end{array}$ & $\begin{array}{l}\text { BEP Terhadap } \\
\text { Produksi }\end{array}$ \\
\hline Jarwo 2:1 & Rp 11.476.669 & 6.200 & Rp 4.160 & Rp 1.851 & 4.970 \\
Jarwo 4:1 & Rp 11.512.762 & 6.100 & Rp 4.160 & Rp 1.887 & 5.065 \\
\hline
\end{tabular}

Sumber : Data Primer (diolah), 2017

Dari Tabel 3 di atas dapat dilihat nilai BEP dari dua sistem tanam yang dibandingkan. Nilai BEP untuk sistem tanam Jajar Legowo 2:1 adalah 4.970 sedangkan nilai BEP untuk sistem tanam Jajar Legowo 4:1 adalah 5.065. Dengan demikian menurut analisis BEP produksi yang paling layak diusahakan untuk menunjang pendapatan petani padi sawah adalah sistem tanam Jajar Legowo 2:1, karena nilai BEP sistem jajar legowo 2:1 terhadap produksi lebih kecil dari produksi yang dihasilkan. Hal ini sesuai dengan pendapat Rahim (2008), jika penerimaan > BEP penerimaan maka sistem tanam tersebut layak digunakan. Atau jika produksi > BEP produksi maka sistem tanam tersebut layak digunakan.

Penulis melakukan pengujian perbedaan rata-rata pendapatan petani sistem jajar legowo 2:1 dengan sistem jajar legowo 4:1. Dengan hasil pengujian apakah ada perbedaan rata-rata pendapatan petani di 3 (tiga) desa lokasi penelitian setelah menggunakan kedua sistem tanam tersebut. Dari data yang diperoleh dalam lampiran menunjukkan adanya perbedaan rata-rata pendapatan petani sistem jajar legowo 2:1 dengan sistem jajar legowo 4:1. 
Untuk melakukan pengujian perbedaan rata-rata pendapatan yang diperoleh oleh petani padi sawah di desa penelitian maka penulis melakukan uji Independen Sample Test. Dari hasil pengolahan data diperoleh hasil bahwa ratarata pendapatan nominal usahatani dengan sistem tanam jajar legowo 2:1 Rp 14.315.331 sedangkan rata-rata pendapatan nominal usahatani dengan sistem tanam jajar legowo 4:1 Rp 13.863.238.

Sistem tanam jajar legowo adalah pola bertanam yang berselang-seling antara dua atau lebih (biasanya dua atau empat) baris tanaman padi dan satu baris kosong. Baris tanaman (dua atau lebih) dan baris kosongnya (setengah lebar di kanan dan di kirinya) disebut satu unit legowo. Bila terdapat dua baris tanam per unit legowo maka disebut legowo 2:1, sementara jika empat baris tanam per unit legowo disebut legowo 4:1, dan seterusnya.

Pada awalnya tanam jajar legowo umum diterapkan untuk daerah yang banyak serangan hama dan penyakit, atau kemungkinan terjadinya keracunan besi. Jarak tanam dua baris terpinggir pada tiap unit legowo lebih rapat dari pada baris yang ditengah (setengah jarak tanam baris yang di tengah), dengan maksud untuk mengkompensasi populasi tanaman pada baris yang dikosongkan. Pada baris kosong, di antara unit legowo, dapat dibuat parit dangkal. Parit dapat berfungsi untuk mengumpulkan keong mas, menekan tingkat keracunan besi pada tanaman padi atau untuk pemeliharaan ikan kecil (muda). Sistem tanam legowo kemudian berkembang untuk mendapatkan hasil panen yang lebih tinggi dibanding sistem tegel melalui penambahan populasi. Selain itu juga mempermudah pada saat pengendalian hama, penyakit, gulma, dan juga pada saat pemupukan.

Mengacu pada rata-rata total penerimaan dan rata-rata total biaya yang dikeluarkan pada kegiatan usahatani padi sawah sistem tanam jajar legowo di 3 desa penelitian kecamatan Kualuh Selatan Kabupaten Labuhanbatu Utara, maka besarnya pendapatan yang diperoleh petani responden di wilayah penelitian menunjukkan bahwa pendapatan petani responden yang menerapkan sistem tanam jajar legowo 2:1 lebih besar dari pada petani responden yang menerapkan sistem tanam jajar legowo 4:1. Hasil ini sesuai dengan penelitian yang dilakukan Abdulrachman et al (2011), menunjukkan bahwa pada pertanaman Legowo $2: 1$ dengan jarak tanam $(25 \times 12,5 \times 50) \mathrm{cm}$ mampu meningkatkan hasil antara 9,63-15,44\% dibanding model tegal.

Hasil yang lebih tinggi dicapai dengan sistem tanam legowo dibandingkan dengan lainnya. Semakin lebar jarak tanam menghasilkan anakan yang lebih 
Safriadi, T.H. Siregar, \& E. H. Khardinata. Analisis Perbedaan Pendapatan Usahatani Padi Sawah Sistem Tanam Jajar Legowo 2:1 Dengan 4:1 di Kecamatan Kualuh Selatan Kabupaten Labuhanbatu Utara.

banyak, pertumbuhan akar yang lebih baik disertai dengan berat kering akar dan tekanan turgor yang tinggi, serta kandungan prolin yang rendah dibandingkan dengan jarak tanam yang lebih sempit. Legowo 4:1 menghasilkan produksi gabah tertinggi, tetapi untuk mendapat bulir gabah berkualitas benih lebih baik jika digunakan legowo 2:1. Legowo 2:1 mampu mengurangi kehampaan akibat efek tanaman pinggir (Badan Litbang Pertanian, 2007).

Kemudahan yang diperoleh pada sistem legowo menurut Kamandalu et al., (2006) dalam hal cara penyiangan, pemupukan serta pemeliharaan tanaman. Sementara itu, permasalahan yang masih dihadapi petani dalam penerapan sistem tanam legowo 4:1 menurut Nazlah (2011) antara lain adalah: (1) adanya petani yang belum yakin terhadap teknologi sistem tanam legowo, kurangnya modal, terbatasnya alat mesin pertanian, dan kurangnya informasi yang mendetail untuk sistem tanam legowo.

Sebenarnya kendala di atas muncul karena tenaga tanam belum terbiasa dan membudaya. Solusi yang ditawarkan untuk menanggulagi masalah di atas salah satunnya menggunakan alat tanam. Alat tanam yang dimaksud adalah alat tanam benih langsung (ATABELA). Agak berbeda dibandingkan tanam bibit dengan transplanter, tanam benih langsung dapat menggunakan drum seeder atau Sedeer Baytani. Seeder Baytani mampu memasukan benih kedalam lubang alur saat dilakukan tarikan. Hal ini dapat menghindarkan terseraknya benih akibat hujan atau serangga dan mampu membuat barisan tanaman lebih rapih. Berikut Sedeer Baytani untuk legowo 4:1 dan legowo 2:1. Perbedaan yang utama antara kedua sedeer ini hanyalah pada panjang pralon tempat pengisian benih, $120 \mathrm{~cm}$ untuk legowo 4:1 sedangkan pada legowo 2:1 adalah 2,25 cm. Lubang keluarnya benih pada sedeer dapat diatur sesuai baris legowo yang diinginkan.

Berdasarkan hasil penelitian dilapangan salah satu faktor yang menyebabkan terdapat perbedaan pendapatan dari kedua sistem tanam tersebut adalah masih kurangnya pengetahuan petani tentang perlakuan kedua sistem tanam tersebut terutama untuk sistem tanam jajar legowo 2:1. Disimpulkan dari data yang diperoleh bahwa total biaya yang dikeluarkan petani sistem tanam jajar legowo 4:1 lebih besar dibandingkan sistem tanam jajar legowo 2:1 sedangkan untuk hasil produksi dari sistem jajar legowo 4:1 lebih sedikit dari sistem jajar legowo 2:1 dengan rata-rata lahan yang digunakan sama yaitu 20 rante $(0,8 \mathrm{Ha})$. Hal ini menyebabkan pendapatan petani untuk sistem tanam jajar legowo 4:1 lebih sedikit dibandingkan sistem jajar legowo 2:1 dengan harga jual kedua sistem tanam sama. 
Masalah yang terjadi pada penjelasan diatas akan menyebabkan sistem yang telah dilakukan petani jajar legowo 4:1 mungkin akan ditinggalkan oleh petani dan akan beralih ke sistem jajar legowo 2:1 dengan alasan pendapatan yang diperoleh lebih besar dari sistem jajar legowo 4:1.

Pendapatan rata-rata yang diperoleh responden petani sistem jajar legowo 4:1 sebesar Rp 13.863.238/Ha/MT, sedangkan rata-rata pendapatan responden petani sistem jajar legowo 2:1 Rp 14.315.331/Ha/MT. Rata-rata hasil pendapatan yang diperoleh oleh petani dengan sistem tanam jajar legowo 2:1 sebesar Rp 14.315.331 per musim tanam. Dimana musim tanam padi berlangsung selama 3 bulan, sehingga per bulannya pendapatan yang diperoleh oleh 1 orang kepala keluarga dirata-ratakan sebesar Rp 4.771.177. Dengan ratarata pendapatan sebesar $\mathrm{Rp}$ 4.771.177/bulan kepala keluarga membiayai kehidupan anggota keluarga dengan rata-rata tanggungan 6 orang. Sedangkan untuk rata-rata hasil pendapatan yang diperoleh oleh petani dengan sistem tanam jajar legowo 4:1 sebesar Rp 13.863.238 per musim tanam. Dimana musim tanam padi berlangsung selama 3 bulan, sehingga per bulannya pendapatan yang diperoleh oleh 1 orang kepala keluarga dirata-ratakan sebesar Rp 4.621.079,33. Dengan rata-rata pendapatan sebesar Rp 4.621.079,33/bulan kepala keluarga dengan sistem jajar legowo 4:1 membiayai kehidupan anggota keluarga dengan rata-rata tanggungan 8 orang. Atas hasil tersebut petani di kecamatan Kualuh Selatan di desa Siamporik, desa Gunung Melayu dan desa Sidua-dua dikategorikan memiliki pendapatan dengan tingkat menengah.

Berdasarkan hasil pengujian hipotesis terhadap perbandingan pendapatan petani yang menerapkan sistem tanam jajar legowo 2:1 dengan petani yang menerapkan sistem tanam jajar legowo 4:1 di desa Siamporik, desa Gunung Melayu dan desa Sidua-dua diperoleh t hitung 2,106 dengan $\alpha$ 5\%, t tabel 2,02269 maka Ho ditolak dimana artinya pendapatan usahatani padi sawah dengan menerapkan sistem tanam jajar legowo 2:1 dan sistem tanam jajar legowo 4:1 yang dilakukan pada Kecamatan Kualuh Selatan Kabupaten Labuhanbatu Utara dengan sampel di 3 desa yaitu desa Siamporik, desa Gunung Melayu dan desa Sidua Dua tidak sama atau berbeda.

\section{SIMPULAN}

Berdasarkan hasil penelitian Kelayakan finansial yang diperoleh atas penggunaan sistem tanam jajar legowo 2:1 dan sistem tanam jajar legowo 4:1 adalah layak diusahakan. Kedua sistem tersebut layak diusahakan. Jika nilai R/C 
Safriadi, T.H. Siregar, \& E. H. Khardinata. Analisis Perbedaan Pendapatan Usahatani Padi Sawah Sistem Tanam Jajar Legowo 2:1 Dengan 4:1 di Kecamatan Kualuh Selatan Kabupaten Labuhanbatu Utara.

rasio > 1, maka dapat disimpulkan bahwa Ho ditolak dan Ha diterima, artinya sistem tanam usahatani padi sawah yang digunakan petani sudah layak secara finansial. Menurut analisis BEP produksi kedua sistem tanam tersebut layak diusahakan, karena jika produksi > BEP produksi maka sistem tanam tersebut layak digunakan. Untuk menunjang pendapatan petani padi sawah adalah sistem tanam Jajar Legowo 2:1, karena nilai BEP sistem jajar legowo 2:1 terhadap produksi lebih kecil dari produksi yang dihasilkan. Bahwa sistem tanam jajar legowo 2 : 1 dengan sistem tanam jajar legowo 4 : 1 berdeda nyata dalam hal pendapatan petani, dimana sistem tanam jajar legowo 2 : 1 lebih besar pendapatnya dibandingkan dengan sistem tanam jajar legowo 4 : 1 secara statistik.

Perlunya sosialisasi dan pelatihan mendalam bagi petani padi sawah di Kabupaten Labuhanbatu Utara Kecamatan Kualuh Selatan yang telah menerapkan sistem tanam jajar legowo 2:1, karena jika seluruh petani menggunakan sistem tersebut diharapkan akan dapat meningkatkan pendapatan rata-rata dari petani padi sawah di Kecamatan Kualuh Selatan untuk masa yang akan dating. Untuk meningkatkan pendapatan, petani harus meminimalisasikan biaya-biaya yang dikeluarkan. Seperti mengurangi jumlah dari Tenaga Kerja Luar Keluarga. Untuk peneliti selanjutnya, penelitian ini hanya menggunakan dua sistem tanam padi dan hanya dilakukan pada 3 desa yang ada di kecamatan Kualuh Selatan, sehingga penulis memberikan saran agar peneliti selanjutnya menambah sistem tanam lain yang digunakan untuk penelitian selanjutnya dan menambah sampel penelitian yang lebih banyak sehingga hasil yang ditemukan lebih baik dan dapat menggambarkan keadaan sebenarnya di lapangan.

\section{DAFTAR PUSTAKA}

Ahmad, S. (2006). Analisis Komparasi Usahatani Pepaya dan Pisang Barangan Di Kabupaten Deli Serdang (Studi Kasus: Desa Negara Kec.STM Hilir Kab.Deli Serdang). Fakultas Pertanian USU. Medan.

Azwar Saihani. (2012). Analisis Faktor Sosial Ekonomi Terhadap Pendapatan Petani Padi Ciherang di Desa Sungai Durait Tengah Kecamatan Babirik Kabupaten Hulu Sungai Utara.

Badan Pusat Statistik. (2014). Propinsi Sumatera Utara, Statistik Nilai Tukar Petani.

Badan Pusat Statistik. (2016). Kabupaten Labuhanbatu Utara dalam Angka 2015.

Badan Pusat Statistik. (2016). Propinsi Sumatera Utara Dalam Angka 2015.

Daniel, M. (2002). Pengantar Ekonomi Pertanian. Bumi Aksara, Jakarta.

Dinas Pertanian Kabupaten Labuhanbatu Utara. (2016). Tentang Luas Areal Pertanian Padi tahun 2015

Harjadi, SS. (2002). Pengantar Agronomi. Gramedia Pustaka. Jakarta. 
Herawati, W.D. (2012). Budidaya Padi. PT Buku Kita.Yogyakarta. Hermanto. (2001). Ilmu Usahatani. Penebar Swadaya, Jakarta.

Hasanah, I. (2007). Bercocok Tanam Padi. Azka Mulia Media. Jakarta. Ibrahim, Yakob. (2010). Studi Kelayakan Bisnis. Bhineka Cipta. Jakarta

Kementrian Pertanian, Badan Penelitian dan Pengembangan Pertanian (BBPT Padi). (2013). Sistem Tanam Legowo

Mubyarto. (2002). Pengantar Ekonomi Pertanian. LP3ES, Jakarta.

Nazir, Moh. (2005). Metode Penelitian Cetakan Keenam. Ghalia Indonesia, Jakarta.

Prawirokusumo, S. 2(000). Ilmu Usaha Tani. BPIE, Yogyakarta.

Putra Pratama. (2014). Analisis Pendapatan dan Kelayakan Usahatani Padi sawah Di Desa Sidondo1 Kecamatan Sigi Birimaru Kabupaten Sigi. Fakultas Pertanian Universitas Tadulako, Palu.

Rahim \& Diah Retno. (2007). Ekonomika Pertanian. Penebar Swadaya, Jakarta

Soekartawi. (2002). Analisis Usahatani. Universitas Indonesia, Jakarta.

Soetopo L.(1993). Teknologi Benih. Rajawali Pers, Jakarta.

Sugeng, H. R., (2002). Bercocok Tanam Padi. Aneka Ilmu. Semarang.

Sugiyono. (2010). Metode Penelitian Bisnis dan Aplikasi. Alfabeta, Bandung.

Suharno. (2009). Bahan Kuliah Serealia. Dinas Pertanian DIY.http://www. distan. ;pemda-diy.go.id 04 Pebruari 2017国.

Suratiyah, Ken. (2009). Ilmu Usaha Tani. Penebar Swadaya : Jakarta.

Wirawan, Baran \& Wahyuni, S. (2002). Memproduksi Benih Bersertifikat.Penebar Swadaya. Jakarta. 